\title{
Prevalence of Infectious Organisms Observed in Cervical Smears Between 1997-2014 at Mubarak Al-Kabeer Hospital, Kuwait
}

"Rana Al-Awadhi, ${ }_{1}^{1}$ Azza Al-Shaheen, ${ }^{2}$ Ahlam Al-Juwaiser, ${ }^{2}$ Sara S. George, ${ }^{3}$ Prem Sharma, ${ }^{4}$ Kusum Kapila

$$
\begin{aligned}
& \text { دراسة مدى انتشار العلدوى الميكروبية في مسحات عنق الرحم في مستشفى } \\
& \text { مبارك الكبير، الكويت في الفترة مابين 2014-1997 }
\end{aligned}
$$

رنا العوضي، عزة الشاهين، أحلام الجويسر، سارا شيرلي جورج، برم شارما، كوسوم كابيلا

ABSTRACT: Objectives: This study aimed to examine gynaecological infectious agents observed in conventional and modified Papanicolaou cervical smears (CS) at a tertiary care hospital in Kuwait. Methods: This retrospective study analysed 121,443 satisfactory CS samples collected between 1997-2014 at the Mubarak Al-Kabeer Hospital, Kuwait. Conventional CS samples were obtained between 1997-2005, while modified CS were obtained between 2006-2014 following the introduction of ThinPrep ${ }^{\circledR}$ testing (Hologic Corp., Bedford, Massachusetts, USA). All samples were initially screened by cytoscreeners before being analysed by cytopathologists to determine the presence of specific infectious agents. Results: Overall, 8,836 (7.28\%) of the cervical samples had infectious agents; of these, $62.48 \%$ were conventional and $37.52 \%$ were modified CS samples. The most frequently observed infectious agents were Candida species (76.05\%), Trichomonas vaginalis (9.72\%), human papillomavirus (HPV; 9.3\%), Actinomyces-like organisms (3.23\%), Chlamydia trachomatis (1.27\%) and the herpes simplex virus (HSV; $0.43 \%)$. There were significantly more cases of Candida species, HPV-associated changes, C. trachomatis, T. vaginalis and Actinomyces-like organisms detected in conventional compared to modified CS samples $(P<0.050$ each). However, there was no statistically significant difference in the frequency of HSV-associated changes $(P=0.938)$. The presence of two infectious agents in the same sample was identified in $0.87 \%$ of samples. Conclusion: Among CS samples collected during an 18-year period, Candida species were most frequently detected, followed by T. vaginalis and HPV. The identification of potential infectious agents is a valuable additional benefit of Papanicolaou smear testing.

Keywords: Cervical Smears; Papanicolaou Test; Infection; Candida; Trichomonas vaginalis; Human Papilloma Virus; Cytology; Kuwait.

الملخص: الهدف: هدفت هذه الدراسة إلى قياس مدى انتشار العدوى الميكروبية عند النساء في المسحات الإعتيادية لعنق الرحم مقارنة

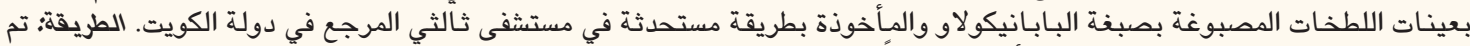

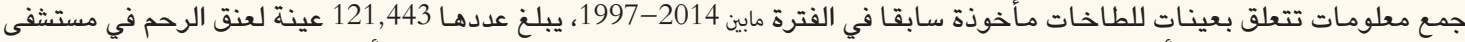

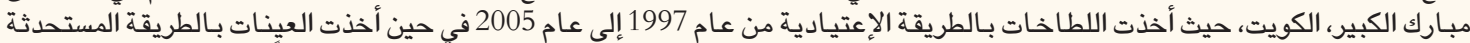

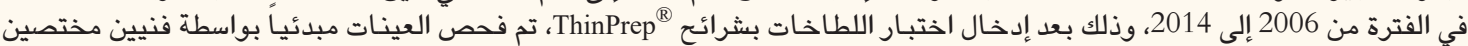

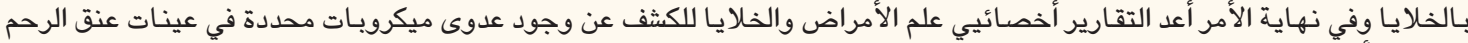

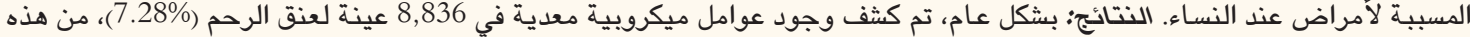
العينات كان هناك نسبة 62.48\% من لطاخـات الطريقة الإعتيادية ونسبة

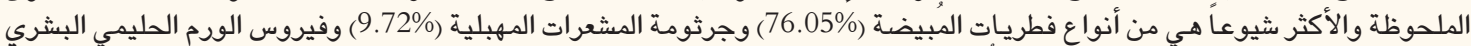

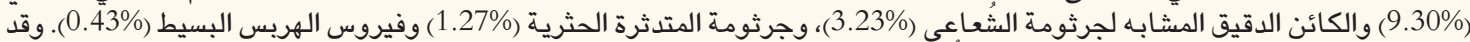

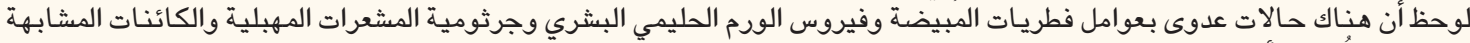

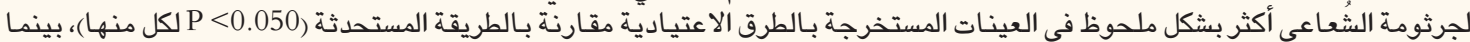

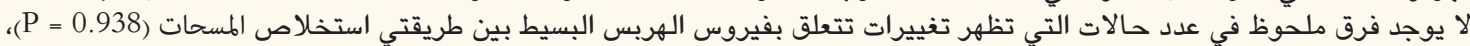

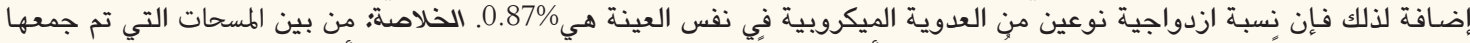

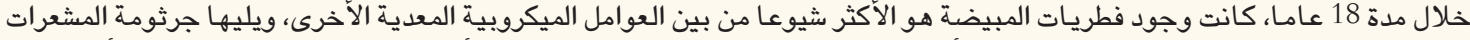

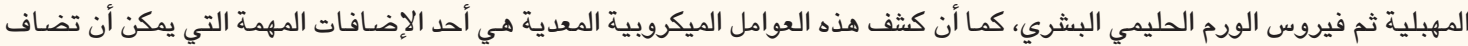

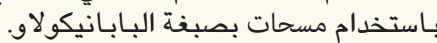

الكلمات المفتاحية: مسحات عنق الرحم؛ فحص البابانيكولاو؛ عدوى؛ فطر المبيضة؛ جرثومة المشعرات المهبلية؛ فيروس الورم الحليمي البثري؛ علم أمراض الخلايا؛ دولة الكويت. 


\section{AdVANCES IN KNOWLEDGE}

This study identified potential infectious agents in Papanicolaou cervical smear samples obtained using two different preparatory techniques. Identifying potential infectious agents represents a valuable additional benefit of cervical smear testing.

Very few similar studies have been conducted in the Gulf Cooperative Council (GCC) region, despite the relatively high incidence of low cervical neoplasia and human papillomavirus infections.

\section{Application to Patient Care}

The results of this study may impact future gynaecological care in Kuwait and other GCC countries, particularly in view of the relatively low rate of gynaecological examinations.

$\mathrm{W}$ ORLDWIDE, MOST CERVICAL SCREENING programmes aim to detect cervical cancer at a pre-invasive stage. However, the Bethesda System used to report gynaecological abnormalities also discloses other microscopic changes in cervical smears (CS), including inflammatory changes in epithelial cells caused by specific infectious agents. ${ }^{1}$ As such, the documentation of cervical organisms represents a valuable additional benefit of cervical cancer screening using Papanicolaou (Pap) smear tests.

In Kuwait, there is unfortunately no formal cervical cancer screening programme. In addition, the results of Pap smears are not well studied, with most previous research originating from one centre, the Mubarak AlKabeer Hospital, a tertiary care hospital which provides cytological diagnostic services to 15 hospitals, 27 clinics and multiple practitioners in Kuwait. ${ }^{2-5}$ The purpose of this study was to determine and compare the prevalence of specific infectious agents in conventional and modified CS samples received over an 18-year period at the cytology laboratory of the Mubarak Al-Kabeer Hospital.

\section{Methods}

This retrospective study reviewed 121,433 conventional and modified Pap CS samples received between 1997-2014 at the cytology laboratory of the Mubarak Al-Kabeer Hospital. Between 1997-2005, conventional CS samples were obtained, while modified CS samples were collected between 2006-2014 following the introduction of ThinPrep ${ }^{\circledR}$ testing (Hologic Corp., Bedford, Massachusetts, USA). The cervical samples were obtained from women attending the outpatient obstetrics and gynaecology departments of general hospitals and clinics in Kuwait with a wide spectrum of gynaecological complaints.

All CS samples were screened and assessed for abnormalities according to the 2001 Bethesda System guidelines. ${ }^{1}$ The CS slides were initially screened by cytoscreeners before being analysed for specific infectious agents or benign or reactive cellular changes associated with inflammation by cytopathologists. Specific infectious agents included the Candida species, Trichomonas vaginalis, Actinomyces-like organisms, Chlamydia trach- omatis and changes associated with herpes simplex virus (HSV) and human papilloma-virus (HPV) infections. In addition, the CS samples were reported as either negative for intraepithelial lesions or malignancy (NILM) or positive for atypical squamous cells, atypical glandular cells, low-grade squamous intra-epithelial lesions (LSILs) or high-grade squamous intra-epithelial lesions (HSILs). ${ }^{1}$ The presence of normal vaginal flora (long rods or Lactobacilli) or shifts in the overgrowth of mixed flora (i.e. bacterial vaginosis) were not evaluated.

Data were analysed using the Statistical Package for the Social Sciences (SPSS), Version 16.0 (IBM Corp., Armonk, New York, USA). Chi-squared or Fisher's exact tests were used to compare the proportions of infectious agents observed in the CS samples. A $P$ value of $<0.050$ was considered statistically significant.

Ethical approval for this study was provided by the Health Science Center of Mubarak Al-Kabeer Hospital (\#VDR/EC/2310). All study procedures were performed in compliance with the ethical standards of the revised Declaration of Helsinki of 2008.

\section{Results}

A total of 121,443 satisfactory CS samples were received during the study period. Of these, 65,338 (53.8\%) samples were conventional CS samples collected between 1997-2005 and 56,105 (46.2\%) were modified ThinPrep ${ }^{\circledR}$ CS samples (Hologic Corp.) collected between 2006-2014. Specific infectious agents were detected in 5,521 (8.45\%) conventional and 3,315 (5.91\%) modified CS samples, resulting in a total of 8,836 (7.28\%) CS samples with infectious agents, of which $62.48 \%$ were conventional and $37.52 \%$ were modified CS samples.

Overall, fewer infectious agents were detected in modified CS samples compared to conventional CS samples [Figure 1]. The most frequently identified infectious organisms were Candida species (76.05\%), T. vaginalis (9.72\%), HPV (9.3\%), Actinomyces-like organisms (3.23\%), C. trachomatis (1.27\%) and HSV (0.43\%). In addition, $88.16 \%$ of CS samples with infectious agents were reported to be NILM. Significantly more Candida species, HPV-associated morphological changes, C. trachomatis, T. vaginalis and Actinomyces-like organisms 


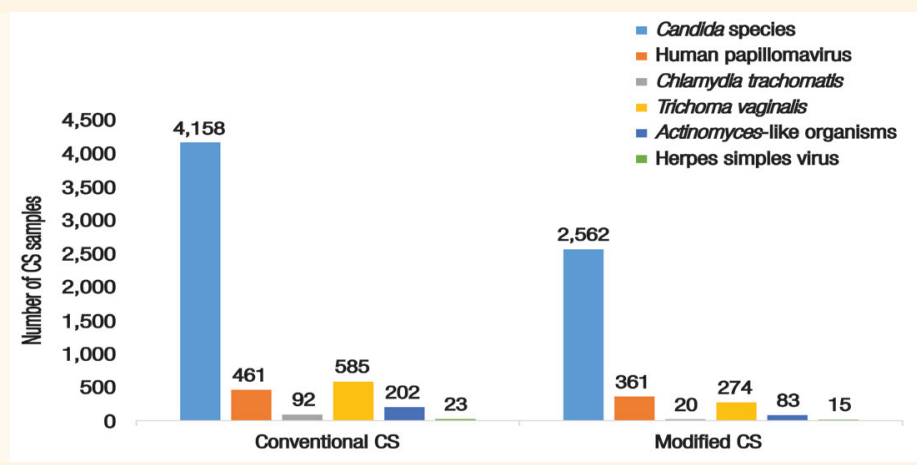

Figure 1: Prevalence of infectious agents observed in conventional and modified cervical smears received from 1997-2014 at the Mubarak Al-Kabeer Hospital, Kuwait $(\mathrm{N}=8,836)$.

$C S=$ cervical smear.

Table 1: Gynaecological infectious agents observed in conventional and modified cervical smears received from 1997-2014 at the Mubarak Al-Kabeer Hospital, Kuwait $(\mathrm{N}=8,836)$

\begin{tabular}{|c|c|c|c|c|c|c|c|}
\hline \multirow{2}{*}{$\begin{array}{l}\text { Cytology } \\
\text { diagnosis }\end{array}$} & \multicolumn{7}{|c|}{ Infectious organism, $\mathbf{n}(\%)$} \\
\hline & Total & $\begin{array}{c}\text { Candida } \\
\text { species }\end{array}$ & HPV & $\begin{array}{l}\text { Chlamydia } \\
\text { trachomatis }\end{array}$ & $\begin{array}{l}\text { Trichomonas } \\
\text { vaginalis }\end{array}$ & $\begin{array}{c}\text { Actinomyces-like } \\
\text { organisms }\end{array}$ & HSV \\
\hline NILM & $7,790(88.16)$ & $6,536(97.26)$ & $0(0)$ & $107(95.54)$ & $829(96.51)$ & $282(98.95)$ & $36(94.74)$ \\
\hline Conventional CS & $4,915(63.09)$ & $4,041(61.83)$ & $0(0)$ & $87(81.31)$ & $565(68.15)$ & $200(70.92)$ & $22(61.11)$ \\
\hline Modified CS & 2,875 (36.91) & 2,495 (38.26) & $0(0)$ & $20(18.69)$ & $264(31.85)$ & $82(29.08)$ & $14(38.89)$ \\
\hline$P$ value & $<0.001$ & $<0.001$ & - & $<0.001$ & 0.002 & 0.007 & 0.944 \\
\hline AGCs & $19(0.22)$ & $15(0.22)$ & $0(0)$ & $0(0)$ & $3(0.35)$ & $1(0.35)$ & $0(0)$ \\
\hline Conventional CS & $13(68.42)$ & $10(66.67)$ & $0(0)$ & $0(0)$ & $2(66.67)$ & $1(100)$ & $0(0)$ \\
\hline Modified CS & $6(31.58)$ & $5(33.33)$ & $0(0)$ & $0(0)$ & $1(33.33)$ & $0(0)$ & $0(0)$ \\
\hline$P$ value & 0.379 & $>0.999$ & - & - & 0.585 & - & - \\
\hline ASCs & $139(1.57)$ & $117(1.74)$ & $0(0)$ & $3(2.68)$ & $18(2.10)$ & $1(0.35)$ & $0(0)$ \\
\hline Conventional CS & $88(63.31)$ & $71(60.68)$ & $0(0)$ & $3(100)$ & $13(72.22)$ & $1(100)$ & $0(0)$ \\
\hline Modified CS & $51(36.69)$ & $46(39.32)$ & $0(0)$ & $0(0)$ & $5(27.78)$ & $0(0)$ & $0(0)$ \\
\hline$P$ value & 0.007 & 0.267 & - & - & 0.546 & - & - \\
\hline LSILs & $832(9.42)$ & $50(0.74)$ & 773 (94.04) & $0(0)$ & $7(0.81)$ & $0(0)$ & $2(5.26)$ \\
\hline Conventional CS & 467 (56.13) & $34(68)$ & $428(55.37)$ & $0(0)$ & $4(57.14)$ & $0(0)$ & $1(50)$ \\
\hline Modified CS & 365 (43.87) & $16(32)$ & $345(44.63)$ & $0(0)$ & $3(42.86)$ & $0(0)$ & $1(50)$ \\
\hline$P$ value & 0.686 & 0.101 & 0.196 & - & 0.755 & - & 0.584 \\
\hline HSILs & $56(0.63)$ & $2(0.03)$ & $49(5.96)$ & $2(1.79)$ & $2(0.23)$ & $1(0.35)$ & $0(0)$ \\
\hline Conventional CS & $38(67.86)$ & $2(100)$ & $33(67.35)$ & $2(100)$ & $1(50)$ & $0(0)$ & $0(0)$ \\
\hline Modified CS & $18(32.14)$ & $0(0)$ & $16(32.65)$ & $0(0)$ & $1(50)$ & $1(100)$ & $0(0)$ \\
\hline$P$ value & 0.014 & - & 0.669 & - & 0.812 & - & - \\
\hline Total & $8,836(100)$ & $6,720(76.05)$ & $822(9.3)$ & $112(1.27)$ & $859(9.72)$ & $285(3.23)$ & $38(0.43)$ \\
\hline Conventional CS & $5,521(62.48)$ & $4,158(61.88)$ & $461(56.08)$ & $92(82.14)$ & $585(68.10)$ & $202(70.88)$ & $23(0.03)$ \\
\hline Modified CS & $3,315(37.52)$ & $2,562(38.13)$ & $361(43.92)$ & $20(17.86)$ & $274 .(31.90)$ & $83(29.12)$ & $15(0.02)$ \\
\hline$P$ value & $<0.001$ & 0.046 & $<0.001$ & $<0.001$ & $<0.001$ & 0.003 & 0.938 \\
\hline
\end{tabular}

$H P V=$ human papillomavirus; HSV = herpes simplex virus; NILM = negative for intraepithelial lesions and malignancy; CS = cervical smears; AGCs = atypical glandular cells; ASCs = atypical squamous cells; LSILs = low-grade squamous intraepithelial lesions; HSILs = high-grade squamous intraepithelial lesions. 
Table 2: Samples with a combination of two infectious agents observed in conventional and modified cervical smears received from 1997-2014 at the Mubarak Al-Kabeer Hospital, Kuwait $(\mathrm{N}=77)$

\begin{tabular}{|c|c|c|c|}
\hline \multirow[t]{2}{*}{$\begin{array}{l}\text { Cytology } \\
\text { diagnosis }\end{array}$} & \multicolumn{3}{|c|}{$\begin{array}{c}\text { Combination of infectious organisms, } \\
\text { n (\%) }\end{array}$} \\
\hline & Total & $\begin{array}{c}\text { Conventional } \\
\text { CS } \\
(\mathbf{n}=52)\end{array}$ & $\begin{array}{c}\text { Modified } \\
\text { CS } \\
(\mathbf{n}=25)\end{array}$ \\
\hline NILM & $38(49.35)$ & $26(50)$ & $12(48)$ \\
\hline $\begin{array}{l}\text { Candida species } \\
\text { and Trichomonas } \\
\text { vaginalis }\end{array}$ & $13(34.21)$ & $9(34.62)$ & $4(33.33)$ \\
\hline $\begin{array}{l}\text { Candida species } \\
\text { and Actinomyces- } \\
\text { like organisms }\end{array}$ & $13(34.21)$ & $8(30.77)$ & $5(41.67)$ \\
\hline $\begin{array}{l}\text { Candida species } \\
\text { and Chlamydia } \\
\text { trachomatis }\end{array}$ & $4(10.53)$ & $4(15.38)$ & $0(0)$ \\
\hline $\begin{array}{l}\text { Candida species } \\
\text { and HSV }\end{array}$ & $4(10.53)$ & $3(11.54)$ & $1(8.33)$ \\
\hline $\begin{array}{l}\text { Trichomonas } \\
\text { vaginalis and } \\
\text { Actinomyces- } \\
\text { like organisms }\end{array}$ & $3(7.89)$ & $2(7.69)$ & $1(8.33)$ \\
\hline $\begin{array}{l}\text { Trichomonas } \\
\text { vaginalis and HSV }\end{array}$ & $1(2.63)$ & $0(0)$ & $1(8.33)$ \\
\hline ASCs & $1(1.30)$ & $1(1.92)$ & $0(0)$ \\
\hline $\begin{array}{l}\text { Candida species } \\
\text { and Trichomonas } \\
\text { vaginalis }\end{array}$ & $1(100)$ & $1(100)$ & $0(0)$ \\
\hline LSILs & $37(48.05)$ & $24(46.15)$ & $13(52)$ \\
\hline $\begin{array}{l}\text { HPV and Candida } \\
\text { species }\end{array}$ & 31 (83.78) & $20(83.33)$ & $11(84.62)$ \\
\hline $\begin{array}{l}\text { HPV and } \\
\text { Trichomonas } \\
\text { vaginalis }\end{array}$ & $4(10.81)$ & $2(8.33)$ & $2(15.38)$ \\
\hline $\begin{array}{l}\text { HPV and } \\
\text { Actinomyces-like } \\
\text { organisms }\end{array}$ & $1(2.7)$ & $1(4.17)$ & $0(0)$ \\
\hline $\mathrm{HPV}$ and $\mathrm{HSV}$ & $1(2.7)$ & $1(4.17)$ & $0(0)$ \\
\hline HSILs & $1(1.3)$ & $1(1.92)$ & $0(0)$ \\
\hline $\begin{array}{l}\mathrm{HPV} \text { and } \\
\text { Trichomonas } \\
\text { vaginalis }\end{array}$ & $1(100)$ & $1(100)$ & $0(0)$ \\
\hline
\end{tabular}

$C S=$ cervical smears; NILM = negative for intraepithelial lesions and malignancy; HSV = herpes simplex virus; ASCs = atypical squamous cells; LSILs = low -grade squamous intraepithelial lesions; HPV = human papillomavirus; HSILs = high-grade squamous intraepithelial lesions.

were detected in conventional compared to modified CS samples $(P<0.050)$. No statistically significant difference was found between the two types of CS samples in relation to $\operatorname{HSV}(P=0.938)$. A greater number of cases with HPV-associated morphological changes were detected in LSIL samples than HSIL samples (94.04\% versus 5.96\%); however, this difference was not significant $(P=0.196$ and 0.669 , respectively). Nevertheless, when the number of cases with HPV-associated morphological changes in the LSIL and HSIL categories were combined, there was a significant difference between modified and conventional CS samples $(P<0.001)$ [Table 1].

A combination of two infectious agents was observed in 77 cases $(0.87 \%)$, of which $67.53 \%$ were conventional and $32.47 \%$ were modified CS samples. Among the conventional CS samples, $84.62 \%$ involved a combination of Candida species and another organism. Overall, two infectious agents were most frequently detected in either NILM (49.35\%) or LSIL (48.05\%) samples [Table 2].

\section{Discussion}

In this study, common gynaecological infectious agents were encountered in $7.28 \%$ of CS samples collected between 1997-2014 at the Mubarak Al-Kabeer Hospital. In comparison, a previous study at the same hospital identified specific infectious agents in $15.2 \%$ of satisfactory CS samples collected between 2002-2007. . These findings therefore indicate a $52.11 \%$ decrease in the number of specific organisms detected. This may be due to the implementation of the ThinPrep ${ }^{\circledR}$ technique (Hologic Corp.), which was only fully achieved in the last nine years of the study period. This assumption is supported by the results of the current study which indicated a drop in the number of specific infectious agents detected in modified compared to conventional CS samples (37.52\% versus 62.48\%).

Previous research has indicated that the incidence of infectious organisms in Kuwait is 4.4\% for samples that show cervical cancer or precancerous changes. ${ }^{5}$ This rate is similar to that of the low invasive cervical carcinoma risk estimate (4/100,000 cases annually) for Kuwait and elsewhere in Asia. ${ }^{6}$ Additionally, Malkawi et al. reported specific inflammation in only $4.8 \%$ of CS samples in Jordan. ${ }^{\text {? }}$

In the current study, the most commonly identified infectious agents were Candida species, followed by T. vaginalis, HPV, Actinomyces-like organisms, C. trachomatis and HSV. A similar pattern was noted in other studies, wherein fungal agents were most prevalent, followed by Trichomonas species. ${ }^{8-12}$ As mentioned earlier, the number of specific infectious agents detected was lower in modified compared to conventional CS samples; this reduction was noted in almost all infectious agents, except HSV. This finding has been supported by other researchers. ${ }^{8,13}$

At the Mubarak Al-Kabeer Hospital, the cytology laboratory employs in-house trained primary screeners whose work is monitored by senior checkers and a chief technician and all slides are signed off by medical practitioners, regardless of abnormalities. As such, differences in the detection rate of infectious agents in the present study were probably not due to the experience 
of the screeners. In addition, the cost of preparation was unlikely to have influenced the results as both conventional and modified samples were collected and examined free of charge. Furthermore, the number of hospitals and clinics providing conventional or modified CS services has remained the same for over 20 years, with all centres utilising both techniques. Nevertheless, the difference in the number of infectious agents detected in conventional and modified CS samples could be due to technical aspects related to the fixative used or the preparation of the modified samples, which may have caused the screener to overlook infectious agents. The fixative could cause shrinkage and therefore the inaccurate identification of organisms in the sample. In addition, filtration could result in a cleaner background and a reduction in inflammatory cell features. ${ }^{13}$

Few studies have focused on HPV distribution in Middle Eastern countries. In the current study, most HPV infections were detected in LSIL samples. In a previous study of modified CS samples collected from women with abnormal cervical cytology in Kuwait, 89\% and 67\% of samples diagnosed as LSIL and HSIL, respectively, were infected with HPV type 16, the most common highrisk genotype. ${ }^{14}$ Another study in Kuwait also showed high-risk HPV DNA in women with squamous intraepithelial lesions, indicating that the viral load was directly related to the severity of the cervical lesions. ${ }^{15}$

\section{Conclusion}

This study described the prevalence of specific infectious agents identified in conventional and modified CS samples collected over an 18-year period at the Mubarak Al-Kabeer Hospital. The identification of potential infectious agents represents a valuable additional benefit of cervical sampling using Pap smear tests; however, it cannot substitute other definitive diagnostic methods.

\section{CONFLICT OF INTEREST}

The authors declare no conflicts of interest.

\section{FUNDING}

No funding was received for this study.

\section{References}

1. Solomon D, Davey D, Kurman R, Moriarty A, O'Connor D, Prey M, et al. The 2001 Bethesda System: Terminology for reporting results of cervical cytology. JAMA 2002; 287:2114-19. doi: 10.1001/ jama.287.16.2114.

2. Luthra UK, Chishti M, Dey P, Jolly SV, Abdulla M, Das DK, et al. Performance of monolayered cervical smears in a gynecology outpatient setting in Kuwait. Acta Cytol 2002; 46:303-10. doi: 10.11 $59 / 000326726$

3. Kapila K, George SS, Al-Shaheen A, Al-Ottibi MS, Pathan SK, Sheikh ZA, et al. Changing spectrum of squamous cell abnormalities observed on Papanicolaou smears in Mubarak Al-Kabeer Hospital, Kuwait, over a 13-year period. Med Princ Pract 2006; 15:253-9. doi: 10.1159/000092986.

4. Al-Awadhi R, Al-Ramadan BA, George SS, Sharma PN, Kapila K. Gynecologic infections seen in cervical smears in Kuwait. Acta Cytol 2010; 54:50-4. doi: 10.1159/000324966.

5. Kapila K, Sharma PN, George SS, Al-Shaheen A, Al-Juwaiser A, Al-Awadhi R. Trends in epithelial cell abnormalities observed on cervical smears over a 21-year period in a tertiary care hospital in Kuwait. Sultan Qaboos Univ Med J 2015; 15:e112-15.

6. Curado MP, Edwards B, Shin HR, Storm H, Ferlay J, Heanue M, et al. Cancer incidence in five continents: Volume IX. IARC Sci Publ 2008; 160:1-837.

7. Malkawi SR, Abu Hazeem RM, Hajjat BM, Hajjiri FK. Evaluation of cervical smears at King Hussein Medical Centre, Jordan, over three and a half years. East Mediterr Health J 2004; 10:676-9.

8. Othman N, Othman NH. Adequacy of cellular material in splitsampling of cervical scrapings for routine cancer screening: An analysis of 702 smears. Malays J Pathol 2012; 34:115-21.

9. Zhou H, Jia Y, Shen J, Wang S, Li X, Yang R, et al. Gynecologic infections seen in ThinPrep cytological test in Wuhan, China. Front Med 2014; 8:236-40. doi: 10.1007/s11684-014-0322-6.

10. Haltas H, Bayrak R, Yenidunya S. To determine of the prevalence of bacterial vaginosis, Candida sp, mixed infections (bacterial vaginosis + Candida sp), Trichomonas vaginalis, Actinomyces sp in Turkish women from Ankara, Turkey. Ginekol Pol 2012; 83:744-8.

11. Salih MM, AlHag FT, Khalifa MA, El Nabi AH. Cervical cytopathological changes among women with vaginal discharge attending teaching hospital. J Cytol 2017; 34:90-4. doi: 10.4103/ JOC.JOC_214_15.

12. Vieira-Baptista P, Grinceviciene S, Bellen G, Sousa C, Saldanha C, Broeck DV, et al. Genital tract infections in an isolated community: 100 women of the Príncipe Island. Infect Dis Obstet Gynecol 2017; 2017:3058569. doi: 10.1155/2017/3058569.

13. Henderson S, Stevens M, Walker T. Rapid review of liquid-based smears as a quality control measure. Diagn Cytopathol 2004; 31:141-6. doi: 10.1002/dc.20091.

14. Al-Awadhi R, Chehadeh W, Jaragh M, Al-Shaheen A, Sharma P, Kapila K. Distribution of human papillomavirus among women with abnormal cervical cytology in Kuwait. Diagn Cytopathol 2013; 41:107-14. doi: 10.1002/dc.21778.

15. George SS, Luthra UK, Chishti M, Shaheen AA, George I. Distribution of human papillomaviruses in women. Med Princ Pract 2000; 9:106-12. doi: 10.1159/000026126. 